\title{
Comparative FISH mapping of ribosomal DNA clusters and TTAGG telomeric sequences to holokinetic chromosomes of eight species of the insect order Psocoptera
}

\author{
Natalia Golub', Boris Anokhin', Valentina Kuznetsova' \\ I Zoological Institute, Russian Academy of Sciences, Universitetskaya emb. 1, St. Petersburg 199034, Russia \\ Corresponding author: Natalia Golub (nvgolub@mail.ru)
}

Academic editor: V. Gokhman | Received 28 November 2019| Accepted 28 November 2019| Published 6December 2019

http://zoobank.org/EEB9D81A-FBC1-4312-8157-07B468F8E87A

Citation: Golub N, Anokhin B, Kuznetsova V (2019) Comparative FISH mapping of ribosomal DNA clusters and TTAGG telomeric sequences to holokinetic chromosomes of eight species of the insect order Psocoptera. Comparative Cytogenetics 13(4): 403-410. https://doi.org/10.3897/CompCytogen.v13i4.48891

\begin{abstract}
Repetitive DNAs are the main components of eukaryotic genome. We mapped the $18 \mathrm{~S}$ rDNA and TTAGG telomeric probe sequences by FISH to meiotic chromosomes of eight species of the order Psocoptera considered a basal taxon of Paraneoptera: Valenzuela burmeisteri (Brauer, 1876), Stenopsocus lachlani Kolbe, 1960, Graphopsocus cruciatus (Linnaeus, 1768), Peripsocus phaeopterus (Stephens, 1836), Philotarsus picicornis (Fabricius, 1793), Amphigerontia bifasciata (Latreille, 1799), Psococerastis gibbosa (Sulzer, 1766), and Metylophorus nebulosus (Stephens, 1836). These species belong to five distantly related families of the largest psocid suborder Psocomorpha: Caeciliusidae, Stenopsocidae, Peripsocidae, Philotarsidae, and Psocidae. We show that all the examined species share a similar location of $18 \mathrm{~S}$ rDNA on a medium-sized pair of autosomes. This is the first study of rDNA clusters in the order Psocoptera using FISH. We also demonstrate that these species have the classical insect (TTAGG) ${ }_{n}$ telomere organization. Our results provide a foundation for further cytogenetic characterization and chromosome evolution studies in Psocoptera.
\end{abstract}

\section{Keywords}

Insecta, psocids, Psocomorpha, meiosis, holokinetic chromosomes, (TTAGG), $18 \mathrm{~S}$ rDNA, FISH

Copyright Natalia Golub et al. This is an open access article distributed under the terms of the Creative Commons Attribution License (CC BY 4.0), which permits unrestricted use, distribution, and reproduction in any medium, provided the original author and source are credited. 


\section{Introduction}

Psocoptera (booklice and barklice) are a small insect order considered a basal taxon of Paraneoptera (Yoshizawa and Saigusa 2001). The order includes 5941 species in 485 genera, 41 families and 3 suborders: Trogiomorpha, Troctomorpha and Psocomorpha (Mockford 2018). To date, 90 psocopteran species (51 genera, 21 families) have been cytogenetically studied, most of them (80 species, 43 genera, 16 families) belonging to the largest suborder Psocomorpha (reviewed in Golub and Nokkala 2009). In this suborder, the majority of species (71 species from 36 genera and 15 families) display $2 \mathrm{n}=16+\mathrm{XX} / \mathrm{X}(0)$ indicative of a particular karyotype conservatism of the group. This karyotype is considered modal and ancestral both for Psocomorpha and for the order Psocoptera in general (Wong and Thornton 1966, Golub 1999, Golub and Nokkala 2009). To date, different derived karyotypes have been reported only for nine species: Amphipsocus japonicus Enderlein, 1906 and Kolbia quisquiliarum Bertkau, 1882 from the family Amphipsocidae $(2 \mathrm{n}=14+\mathrm{XX} /$ neo-XY); Elipsocus moebiusi Tetens, 1891 and Loensia variegata (Latreilee, 1799) from the families Elipsocidae and Psocidae, respectively $(2 \mathrm{n}=12+\mathrm{XX} / \mathrm{X}(0)$; Neopsocopsis hitricornis (Reuter, 1893), Metylophorus nebulosus (Stephens, 1836), and Amphigerontia jezoensis Okamoto, 1907 from the family Psocidae $(2 \mathrm{n}=14+\mathrm{XX} / \mathrm{X}(0)$; Stenopsocus lachlani Kolbe, 1960 and Stenopsocus aphidiformis Enderlein, 1906 from the family Stenopsocidae $(2 \mathrm{n}=22+\mathrm{XX} / \mathrm{X}(0))$.

Psocoptera are characterized by holokinetic chromosomes (Meinander et al. 1974, Golub and Nokkala 2009), which are known to lack such physical landmarks as primary constrictions (the centromeres) and, thus, show no distinguishable markers that could be studied by conventional techniques. In the majority of psocid species, the chromosomes are small and of similar size, making it impossible to identify individual chromosomes. Although karyotypes have been described for many psocid species, individual chromosomes were not identified in most of these reported karyotypes. Such chromosome sets, therefore, are not comparable among related species and cannot be used for evolutionary studies.

The application of banding techniques to chromosome studies of Psocoptera is scarce (Golub and Nokkala 2001, Golub et al. 2004). Golub et al. (2004) used C-banding, silver impregnation and sequence-specific fluorochromes $\mathrm{CMA}_{3}$ and DAPI to study male meiotic karyotypes of Psococerastis gibbosa (Sulzer, 1766) with $2 \mathrm{n}=16+\mathrm{X}(0)$, Blaste conspurcata (Rambur, 1842) with $2 \mathrm{n}=16+\mathrm{X}(0)$, and Amphipsocus japonicus with $2 \mathrm{n}=14+\mathrm{neo}-\mathrm{XY}$. Based on the results obtained, the authors had concluded that NORs (nucleolus organizer regions) were located differently in these species: on an autosomal bivalent, on the X chromosome, and on the neo-XY bivalent, respectively. We believe however that additional studies are needed to confirm the precise localization of NORs in the above species. Using C-banding, the authors found minor interspecific differences in amount, molecular composition and localization of C-heterochromatin as well as some analogous differences between various chromosomes of a particular species.

Our knowledge of karyotype structure and evolution in Psocoptera could be improved by the implementation of molecular cytogenetic approaches. Fluorescence 
in situ hybridization (FISH) has become the most important technique for tracing individual chromosomes in holokinetic insects (e.g., Panzera et al. 2012, 2015, Maryańska-Nadachowska et al. 2013, 2018, Mandrioli et al. 2014, Kuznetsova et al. 2015, Anjos et al. 2016, Golub et al. 2017, Salanitro et al. 2017, Grozeva et al. 2019). It was shown in some case studies that species with the same chromosome complement differ in the number and location of rDNA sites (Panzera et al. 2012, 2015, Maryańska-Nadachowska et al. 2013, Golub et al. 2017). Moreover, some higher insect taxa were shown to differ in respect to the presence/absence of the insect-type telomere motif (TTAGG) ${ }_{n}$. Specifically, such variation has been demonstrated for some Paraneoptera, e.g. Hemiptera, where more basal taxa appear to have the ancestral insect telomere motif (TTAGG) ${ }_{n}$ while more advanced taxa have lost this telomeric sequence (reviewed in Kuznetsova et al. 2019). The only psocid species studied so far by FISH, Stenopsocus lachlani (Psocomorpha, Stenopsocidae), was documented to have the (TTAGG) ${ }_{\mathrm{n}}$ telomere motif (Frydrychová et al. 2004).

Here, we used FISH with the telomeric TTAGG and $18 \mathrm{~S}$ rDNA probes to study male meiotic chromosomes of Valenzuela burmeisteri (Brauer, 1876), Stenopsocus lachlani, Graphopsocus cruciatus (Linnaeus, 1768), Peripsocus phaeopterus (Stephens, 1836), Philotarsus picicornis (Fabricius, 1793), Amphigerontia bifasciata (Latreille, 1799), Psococerastis gibbosa, and Metylophorus nebulosus. The standard karyotypes of these species were previously reported (reviewed in Golub and Nokkala 2009). We demonstrate that the above species, belonging to five different families of the largest suborder Psocomorpha (Caeciliusidae, Stenopsocidae, Peripsocidae, Philotarsidae, and Psocidae), are characterized by conserved karyotypes in respect to telomere composition and rDNA location. This is the first study of rDNA clusters in the order Psocoptera using FISH.

\section{Material and methods}

The information on the localities where the specimens were collected and on the number of specimens/nuclei examined is presented in Table 1. Only male adult specimens were analyzed. Males were fixed in the Carnoy fixative $(3: 1 ; 96 \%$ ethanol and glacial acetic acid) and stored at $4{ }^{\circ} \mathrm{C}$. Testes were dissected out in a drop of $45 \%$ acetic acid and squashed. The cover slips were removed using dry ice. Prior to staining, the preparations were examined by phase contrast microscopy.

Fluorescence in situ hybridization was performed according to the published protocol (Grozeva et al. 2015) with minor modifications. The target $18 \mathrm{~S}$ rDNA probe (about $1200 \mathrm{bp}$ fragment) was PCR amplified and labelled with biotin-11-dUTP (Fermentas, EU) using primers: 18SrRNA_F 5'-GATCCTGCCAGTAGTCATATG-3', 18SrRNA_R 5'-GAGTCAAATTAAGCCGCAGG-3' (Anokhin et al. 2010). Genomic DNA was extracted from the true bug Pyrrhocoris apterus (Linnaeus, 1758). An initial denaturation period of $3 \mathrm{~min}$ at $94^{\circ} \mathrm{C}$ was followed by 35 cycles of $30 \mathrm{~s}$ at $94^{\circ} \mathrm{C}$, annealing for $30 \mathrm{~s}$ at $55.5^{\circ} \mathrm{C}$ and extension for $1.5 \mathrm{~min}$ at $72{ }^{\circ} \mathrm{C}$, with a final extension step of $3 \mathrm{~min}$ at $72{ }^{\circ} \mathrm{C}$. The telomere probe (TTAGG) ${ }_{n}$ was amplified by 
Table I. Material studied.

\begin{tabular}{|c|c|c|}
\hline Species & Collection date and localities & $\begin{array}{l}\text { Number of studied } \\
\text { males / nuclei }\end{array}$ \\
\hline \multicolumn{3}{|l|}{ Fam. Caeciliusidae } \\
\hline Valenzuela burmeisteri & $\begin{array}{l}\text { Russia, the Altai Republic, Artybash vic., } \\
51^{\circ} 47^{\prime} 28^{\prime \prime N}, 87^{\circ} 15^{\prime} 21^{\prime \prime W} \text { July, } 2019\end{array}$ & $4 / 12$ \\
\hline \multicolumn{3}{|l|}{ Fam. Stenopsocidae } \\
\hline Stenopsocus lachlani & $\begin{array}{l}\text { Russia, the Altai Republic, Artybash vic., } \\
51^{\circ} 47^{\prime} 28^{\prime \prime} \mathrm{N}, 87^{\circ} 15^{\prime} 21^{\prime \prime} \text {, July, } 2019\end{array}$ & $2 / 22$ \\
\hline Graphopsocus cruciatus & $\begin{array}{l}\text { Russia, Voronezh region, Maklok vic., } \\
51^{\circ} 48^{\prime} 42^{\prime \prime N}, 39^{\circ} 24^{\prime} 51^{\prime \prime W} \text {, August, } 2018\end{array}$ & $4 / 18$ \\
\hline \multicolumn{3}{|l|}{ Fam. Peripsocidae } \\
\hline Peripsocus phaeopterus & $\begin{array}{l}\text { Russia, the Altai Republic, Artybash vic., } \\
51^{\circ} 47^{\prime} 28^{\prime \prime N}, 87^{\circ} 15^{\prime} 21^{\prime \prime W} \text { July, } 2019\end{array}$ & $6 / 30$ \\
\hline \multicolumn{3}{|l|}{ Fam. Philotarsidae } \\
\hline Philotarsus picicornis & $\begin{array}{l}\text { Russia, the Altai Republic, Artybash vic., } \\
51^{\circ} 47^{\prime} 28^{\prime \prime} \mathrm{N}, 87^{\circ} 15^{\prime} 21^{\prime \prime} \mathrm{W}, \text { July, } 2019\end{array}$ & $6 / 42$ \\
\hline \multicolumn{3}{|l|}{ Fam. Psocidae } \\
\hline Amphigerontia bifasciata & $\begin{array}{l}\text { Russia, Karachay-Cherkess Republic, Teberda } \\
\text { vic., } 43^{\circ} 27^{\prime} 00^{\prime \prime N}, 41^{\circ} 45^{\prime} 00^{\prime \prime W} \text { July, } 2017\end{array}$ & $2 / 10$ \\
\hline Metylophorus nebulosus & $\begin{array}{l}\text { Russia, the Altai Republic, Artybash vic., } \\
51^{\circ} 47^{\prime} 28^{\prime \prime N}, 87^{\circ} 15^{\prime} 21^{\prime \prime W} \text { July, } 2019\end{array}$ & $5 / 28$ \\
\hline Psococerastis gibbosa & $\begin{array}{l}\text { Russia, the Altai Republic, Artybash vic., } \\
51^{\circ} 47^{\prime} 28^{\prime \prime} \mathrm{N}, 87^{\circ} 15^{\prime} 21^{\prime \prime W} \text { July, } 2019\end{array}$ & $4 / 46$ \\
\hline
\end{tabular}

PCR and labeled with rhodamine-5-dUTP (GeneCraft, Köln, Germany) using primers: TTAGG_F 5'-TAACCTAACCTAACCTAACCTAA-3' and TTAGG_R 5'-GGTTAGGTTAGGTTAGGTTAGG-3' (Grozeva et al. 2011). An initial denaturation period of 3 min at $94{ }^{\circ} \mathrm{C}$ was followed by 30 cycles of $45 \mathrm{~s}$ at $94^{\circ} \mathrm{C}$, annealing for $30 \mathrm{~s}$ at $50^{\circ} \mathrm{C}$ and extension for $50 \mathrm{~s}$ at $72^{\circ} \mathrm{C}$, with a final extension step of $3 \mathrm{~min}$ at $72{ }^{\circ} \mathrm{C}$. The chromosome preparations were treated with $100 \mu \mathrm{g} / \mathrm{ml} \mathrm{RNase}$ A and $5 \mathrm{mg} / \mathrm{ml}$ pepsin solution to remove excess RNA and proteins. Chromosomes were denatured in the hybridization mixture containing labelled $18 \mathrm{~S}$ rDNA and (TTAGG) ${ }_{n}$ probes with an addition of salmon sperm blocking reagent and then hybridized for $42 \mathrm{~h}$ at $37^{\circ} \mathrm{C}$. $18 \mathrm{~S}$ rDNA probes were detected with NeutrAvidin-Fluorescein conjugate (Invitrogen, Karlsbad, CA, USA). The chromosomes were mounted in an antifade medium (ProLong Gold antifade reagent with DAPI, Invitrogen) and covered with a glass coverslip.

\section{Results and discussion}

\section{Standard karyotypes}

All chromosome numbers fully correspond to the previously published karyotype data for all studied species (reviewed in Golub and Nokkala 2009). Males of Valenzuela burmeisteri, Graphopsocus cruciatus, Peripsocus phaeopterus, Philotarsus picicornis, Amphigerontia bifasciata, and Psococerastis gibbosa were confirmed to have $2 \mathrm{n}=16+\mathrm{X}(0)$, 
the chromosome complement known to be the most characteristic and presumably ancestral for Psocoptera (Wong and Thornton 1966, Golub 1999, Golub and Nokkala 2009). Males of Stenopsocus lachlani and Metylophorus nebulosus were confirmed to have $2 \mathrm{n}=22+\mathrm{X}(0)$ and $2 \mathrm{n}=14+\mathrm{X}(0)$, respectively. Thus, even though the sex chromosome system is the same among all studied species, the number of autosomes differs considerably between them. Based on the meiotic figures, we can infer that the karyotype structure of these species is uniform: all the bivalents constitute a decreasing size series, which makes identifying individual bivalents almost impossible. The only exception to this rule is the karyotype of $M$. nebulosus. In this species, metaphase I nuclei were shown to include seven bivalents with a particular element being significantly larger than the other ones (Meinander et al. 1974, Golub 1999, present study).

\section{FISH mapping of $18 S$ rDNA repeats}

In each of the species studied, FISH mapping with the $18 \mathrm{~S} \mathrm{rDNA}$ probe revealed two large clusters located in a sub-terminal position on the homologues of a medium-sized bivalent (Fig. 1a-h). The signals could be observed either in the chiasmate or the opposite region of the rDNA-carrying bivalent, thus suggesting that the same homologue is able to orient differently within the bivalent. Following current knowledge, all the studied species are suggested to share a similar chromosomal location of the rRNA genes on the same pair of autosomes. However, this speculation is premature, since the precise identification of particular bivalents in psocid karyotypes is currently impossible due to the absence of additional differential chromosomal landmarks.

\section{FISH mapping of TTAGG telomeric repeats}

In each of the species studied, FISH mapping with TTAGG repeats revealed signals located in a telomeric position on the chromosomes. The signals were visible in most but not all terminal regions of meiotic chromosomes. Moreover, in some species, the signals were bright (Fig. 1b, e, g, h), whereas in other species they were not so clearly defined (Fig. 1a, c, d, f).

A previous investigation by Frydrychová et al. (2004) documented presence of the (TTAGG) ${ }_{\mathrm{n}}$ telomere motif in S. lachlani (Stenopsocidae). Despite the variability in the signal intensity, the currently existing data on eight genera from five different families lead to the conclusion that psocids, at least those from the suborder Psocomorpha, share the telomere structure (TTAGG) ${ }_{n}$ known to be characteristic of the majority of insect orders and considered ancestral for the class Insecta in general (Kuznetsova et al. 2019).

In conclusion, the present study contributes to the understanding of the chromosome structure of Psocoptera and provides a foundation for further cytogenetic characterization and chromosome evolution studies in this group. 

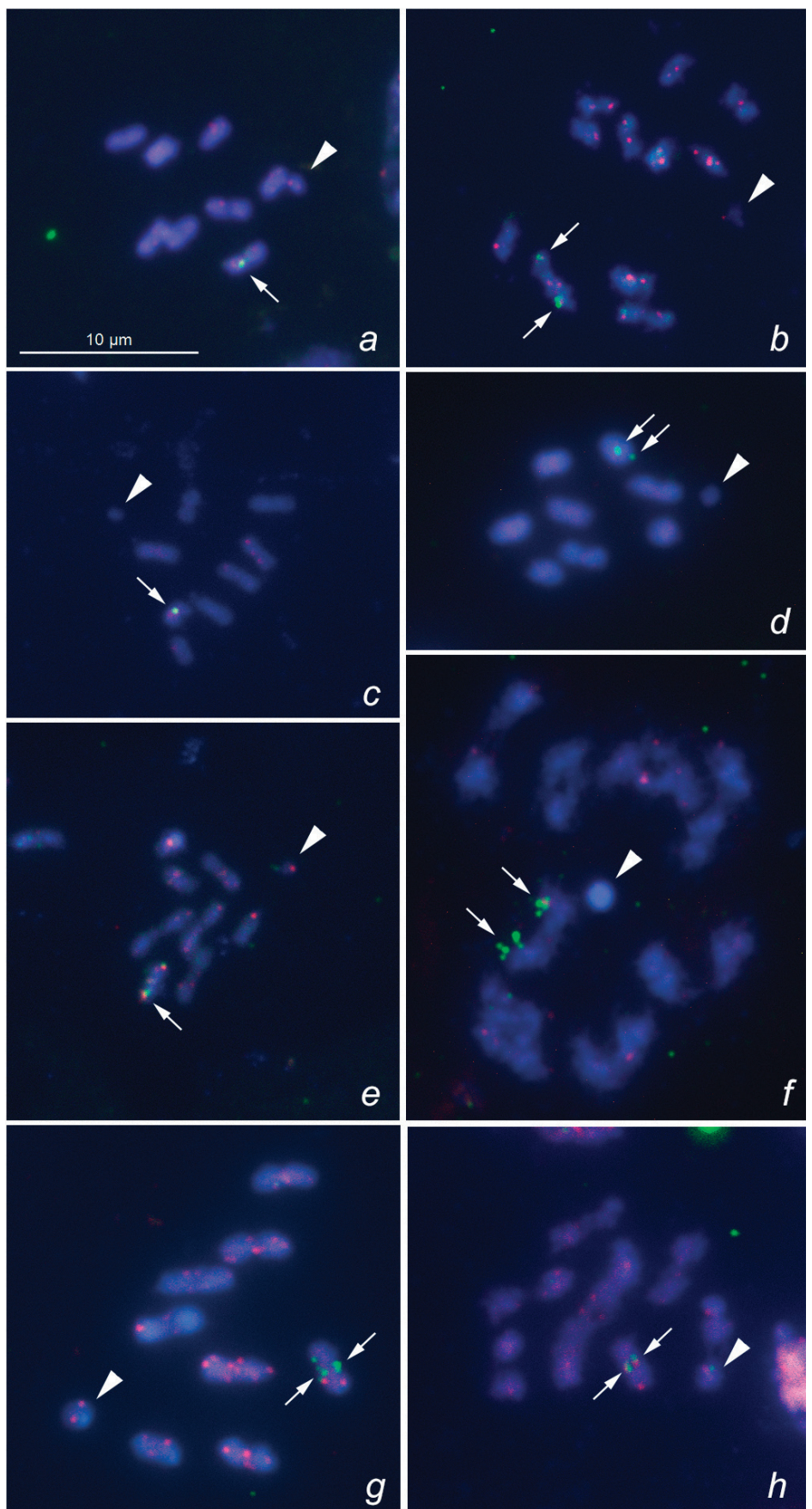

Figure I. FISH mapping of TTAGG telomeric sequences (red signals) and $18 \mathrm{~S}$ rDNA (green signals) to meiotic chromosomes of Psocoptera a Valenzuela burmeisteri, MI, $\mathrm{n}=8+\mathrm{X} \mathbf{b}$ Stenopsocus lachlani, MI, $\mathrm{n}=11+\mathrm{X} \mathbf{c}$ Graphopsocus cruciatus, MI, $\mathrm{n}=8+\mathrm{X} \mathbf{d}$ Peripsocus phaeopterus, MI, $\mathrm{n}=8+\mathrm{X}$ e Philotarsus picicornis, MI, $\mathrm{n}=8+\mathrm{X} \mathbf{f}$ Amphigerontia bifasciata, diakinesis, $\mathrm{n}=8+\mathrm{X} \mathbf{g}$ Psococerastis gibbosa, MI, $\mathrm{n}=$ $8+\mathrm{X} \mathbf{h}$ Metylophorus nebulosus, MI, $\mathrm{n}=7+\mathrm{X}$. Arrowheads and arrows indicate sex chromosomes and $18 \mathrm{~S}$ rDNA signals, respectively. Scale bar: $10 \mu \mathrm{m}$. 


\section{Acknowledgements}

The present study was supported by the research project no. AAAAA19-119020790106-0, by the research grants from the Russian Foundation for Basic Research Nos 17-04-00828 and 19-54-18002, and by the Presidium of the RAS, Program No. 41 "Biodiversity of natural systems and biological resources of Russia".

\section{References}

Anjos A, Rocha GC, Paladini A, Mariguela TC, Cabral-de-Mello DC (2016) Karyotypes and repetitive DNA evolution in six species of the genus Mahanarva (Auchenorrhyncha: Cercopidae). Cytogenetic and Genome Research 149:321-327. https://doi.org/10.1159/000450730

Anokhin B, Hemmrich-Stanisak G, Bosch TCG (2010) Karyotyping and single-gene detection using fluorescence in situ hybridization on chromosomes of Hydra magnipapillata. Comparative Cytogenetics 4(2): 97-110. https://doi.org/10.3897/compcytogen.v4i2.41

Frydrychová R, Grossmann P, Trubač P, Vítková M, Marec F (2004) Phylogenetic distribution of TTAGG telomeric repeats in insects. Genome 47: 163-178. https://doi.org/10.1139/g03-100 Golub NV (1999) Review of karyological data on psocids (Psocoptera) and description of karyotypes of 13 species. Entomologicheskoe Obozrenie 78(2): 376-390. [In Russian, with English translation in Entomological Review 79: 412-424]

Golub NV, Nokkala S (2001) The karyotypes of two bark-lice species (Psocoptera, Psocomorpha, Amphipsocidae): the first description of the Neo-XY sex chromosome system in Psocoptera. Folia biologica (Kraków) 49(3-4): 153-156.

Golub NV, Nokkala S (2009) Chromosome numbers in eight species of Palaearctic Psocoptera (Insecta). Comparative Cytogenetics 3(1): 33-41. https://doi.org/10.3897/compcytogen.v3i1.6

Golub NV, Nokkala S, Kuznetsova VG (2004) Holocentric chromosomes of psocids (Insecta, Psocoptera) analysed by C-banding, silver impregnation and sequence specific fluorochromes $\mathrm{CMA}_{3}$ and DAPI. Folia biologica (Kraków) 52(3-4): 143-149. https://doi. org/10.3409/1734916044527476

Golub NV, Golub VB, Kuznetsova VG (2017) Distribution of the major rDNA loci among four hemipteran species of the family Tingidae (Heteroptera, Cimicomorpha). Folia Biologica (Kraków) 65(3): 155-158. https://doi.org/10.3409/fb65_3.155

Grozeva S, Kuznetsova VG, Anokhin BA (2011) Karyotypes, male meiosis and comparative FISH mapping of $18 \mathrm{~S}$ ribosomal DNA and telomeric (TTAGG) repeat in eight species of true bugs (Hemiptera, Heteroptera). Comparative Cytogenetics 5(4): 355-374. https:// doi.org/10.3897/compcytogen.v5i4.2307

Grozeva S, Anokhin B, Kuznetsova VG (2015) Bed bugs (Hemiptera). In: Sharakhov I (Ed.) Protocols for Cytogenetic Mapping of Arthropod Genomes. CRC press, Taylor \& Francis, Boca Raton, 285-326. https://doi.org/10.1201/b17450-9

Grozeva S, Anokhin BA, Simov N, Kuznetsova VG (2019) New evidence for the presence of the telomere motif (TTAGG) $n$ in the family Reduviidae and its absence in the families Nabidae and Miridae (Hemiptera, Cimicomorpha). Comparative Cytogenetics 13(3): 283-295. https://doi.org/10.3897/CompCytogen.v13i3.36676 
Kuznetsova VG, Grozeva S, Gokhman VE (2019) Telomere structure in insects: A review. Journal of Zoological Systematics and Evolutionary Research 19 November, 2019. https://doi. org/10.1111/jzs.12332

Kuznetsova VG, Grozeva SM, Hartung V, Anokhin BA (2015) First evidence for (TTAGG) telomeric sequence and sex chromosome post-reduction in Coleorrhyncha (Insecta, Hemiptera). Comparative Cytogenetics 9(4): 523-532. https://doi.org/10.3897/CompCytogen.v9i4.5609

Mandrioli M, Zanasi F, Manicardi GC (2014) Karyotype rearrangements and telomere analysis in Myzus persicae (Hemiptera, Aphididae) strains collected on Lavandula sp. plants. Comparative Cytogenetics 8(4): 259-274. https://doi.org/10.3897/CompCytogen.v8i4.8568

Maryańska-Nadachowska A, Kuznetsova VG, Karamysheva TV (2013) Chromosomal location of rDNA clusters and TTAGG telomeric repeats in eight species of the spittlebug genus Philaenus (Hemiptera: Auchenorrhyncha: Aphrophoridae). European Journal of Entomology 110(3): 411-418. https://doi.org/10.14411/eje.2013.055

Maryańska-Nadachowska A, Kuznetsova VG, Golub NV, Anokhin BA (2018) Detection of telomeric sequences and ribosomal RNA genes in holokinetic chromosomes of five jumping plant-lice species: First data on the superfamily Psylloidea (Hemiptera: Sternorrhyncha). European Journal of Entomology 115: 632-640. https://doi.org/10.14411/eje.2018.061

Meinander M, Halkka O, Söderlund V (1974) Chromosomal evolution in the Psocoptera. Notulae Entomologicae 54: 81-84.

Mockford EL (2018) Biodiversity of Psocoptera. In: Foottit RG, Adler PH (Eds) Insect Biodiversity: Science and Society. Wiley Online Library, 417-456. https://doi. org/10.1002/9781118945582.ch16

Panzera Y, Pita S, Ferreiro MJ, Ferrandis I, Lages C, Pérez R, Silva AE, Guerra F, Panzera F (2012) High dynamics of rDNA cluster location in kissing bug holocentric chromosomes (Triatominae, Heteroptera). Cytogenetic and Genome Research 138: 56-67. https://doi. org/10.1159/000341888

Panzera F, Pita S, Nattero J, Panzera Y, Galvão C, Chavez T, Arias AR, Téllez LC, Noireau F (2015) Cryptic speciation in the Triatoma sordida subcomplex (Hemiptera, Reduviidae) revealed by chromosomal markers. Parasites and Vectors 8: 495. https://doi.org/10.1186/ s13071-015-1109-6

Salanitro LB, Massaccesi AC, Urbisaglia S, Bressa MJ, Chirino MG (2017) A karyotype comparison between two species of bordered plant bugs (Hemiptera, Heteroptera, Largidae) by conventional chromosome staining, C-banding and rDNA-FISH. Comparative Cytogenetics 11(2): 239-248. https://doi.org/10.3897/CompCytogen.v11i2.11683

Yoshizawa K, Saigusa T (2001) Phylogenetic analysis of paraneopteran orders (Insecta: Neoptera) based on forewing base structure, with comments on monophyly of Auchenorrhyncha (Hemiptera). Systematic Entomology 26: 1-13. https://doi.org/10.1046/j.13653113.2001.00133.x

Wong SK, Thornton IWB (1966) Chromosome numbers of some Psocid genera (Psocoptera). Nature 211: 214-215. https://doi.org/10.1038/211214a0 